\title{
What makes external financial supporters engage in university spin-off seed investments: \\ Entrepreneurs' capabilities or social networks?
}

\author{
Thanh Huynh \\ Faculty of Management \\ Bournemouth University, United Kingdom
}

This study aims to enrich our knowledge of the influences of social networks and capabilities of entrepreneurial teams have on the engagement of external seed investors by exploring academic entrepreneurial teams. This paper studies the capabilities and characteristics of social networks of entrepreneurial teams based upon resource-based view and the conceptual model of social networks. The results from an examination of the sample of 181 Spanish university spin-offs demonstrate that by exploiting social networks an entrepreneurial team can shape its capabilities which, in turn, improve its ability to access various types of external seed capital sources. Thus, the paper has implications for universities in training and policy development to support spin-off's activity, especially to build entrepreneurial teams with capabilities to pitch for external seed capital.

Keywords: University spin-offs; entrepreneurial teams; resource-based view; social networks; seed capital

\section{Introduction}

Early-stage finance, including primary and second rounds of funding, is a major issue for university entrepreneurship activities to develop inventions or know-how into practical applications (Lindstrom and Olofsson, 2001). It is suggested that while good fundraising is perceived to assist entrepreneurs to be more commercially productive than others (Powers and Mcdougall, 2005), undercapitalization can be one of the consistent causes of failures not only at the foundation stage but also into the growth period of a new venture (Rosman and O'neill, 1993; Huynh, et al., 2017). An entrepreneurial team, defined as two or more individuals who jointly established a business (Kamm, et al., 1990), must explore suitable financial sources within the capital markets depending upon the growth goals, the nature of ownership and sector (Riding, et al., 2012). Lindstrom and Olofsson (2001) argue that while these financial sources are available, how to access them has become a key challenge for entrepreneurial teams because of the effects of financial constraints caused by capital market imperfections.

Given the difficulties in accessing external financial resources, the determination of the factors underpinning an investor's willingness to make such early-stage investments is important for entrepreneurs, researchers and policy makers (Rasmussen and Sørheim, 2012). In early-stage financing, extant research has found that each investor has different scales and ratings of a new venture's abilities based upon non-financial criteria, such as the investor's perception of the business model, potential market, growth orientation (Mason and Harrison, 2004), technology, market and management stage (Douglas and Shepherd, 2002), time to exit (Wiltbank, et al., 2009) and the presentation of entrepreneurial teams (Clark, 2008; Franke, et al., 2008). Others have found that the presence of well-balanced teams with sufficient business capabilities including leadership potential, industrial expertise, 
managerial skills and engineering/technological skills are the most important criteria (Muzyka, et al., 1996; Shepherd and Zacharakis, 1999; Silva, 2004; Bjørnåli, et al., 2010). In general, potential investors, when making the investment decision, tend look for signals of future success from entrepreneurial teams (Meseri and Maital, 2001; Wiltbank, et al., 2009).

Within the university spin-off (USO) context, while numerous studies have focused on funding activities for early organizing efforts in business registration, the initial product development or market entry (Clarysse, et al., 2007; Tsukagoshi, 2008; Ortín-Ángel and Vendrell-Herrero, 2010; Soetanto and Van Geenhuizen, 2015; Huynh, 2016), seed capital needed for research activities and developing the initial business concept has received less attention (Rasmussen and Sørheim, 2012). However, the results from prior studies associated with the early-stage finance of new ventures or funding activities for early organizing efforts may not held within the context of USO's seed capital, which strongly links to unknowable risks (Huang and Pearce, 2015). A study of Rasmussen and Sørheim (2012) has explained how some governments use various seed funding schemes to help USOs overcome the obstacles derived from the liabilities of newness and investor's incentive to invest in later stages of a spin-off's development. Other studies have indicated that the social networks and capabilities of entrepreneurial teams positively influence the decisions of investors to make early-stage investments in USOs (Rasmussen and Sørheim, 2012; Huynh, 2016). A limited number of extant literature has studied the factors underpin the decision of external financial supporters to engage in seed investments does not address the underlying factors that facilitate such financing process. In the context of university spin-offs, with the acknowledged commercial limitations of academic entrepreneurial teams, this paper posits that the quality of the entrepreneurial team, identified by its networks and capabilities prior to incorporation, significantly influence the likelihood that the team obtain external seed capital.

Hence, this paper addresses two fundamental questions: Which capabilities of entrepreneurial teams influence the engagement of seed investments in university spin-offs? Which characteristics of social networks of entrepreneurial teams accelerate the engagement of seed investments in university spin-offs? To answer those research questions and contribute to the theoretical foundation of university spin-off studies, this study examines the engagement of external financial supporters in the seed investments of university spin-offs under the impact of capabilities and social networks of entrepreneurial teams. To study the capabilities of an academic entrepreneurial team, this study employs resource-based view (Barney, 1991), which emphasizes the internal idiosyncratic capabilities. The social networks of the team will be analysed based upon the social network model suggested by Amit and Zott (2001), and Hoang and Antoncic (2003), and the theoretical research framework is constructed based upon emotion-cognition interaction theory introduced by Malatesta and Wilson (1988). This research draws a sample of 181 Spanish university spin-offs based in 35 universities across all regions of Spain. Each spin-off was created and developed by an entrepreneurial team and responses were obtained from members of the teams. The findings indicate that the capabilities of entrepreneurial teams affect the decisions of financial supporters to engage in seed investments. The social networks of entrepreneurial teams are likely to have both direct and indirect influences on the decisions of financial supporters through their impact on the capabilities of entrepreneurial teams. To make those arguments, this research first constructs research hypotheses based upon extant literatures in social networks, entrepreneurial 
capabilities and intuitive judgment in seed funding. This research then estimates and examines those hypotheses based upon data drawn from 181 USOs in Spain. The paper ends with the discussion of the results from the statistical analysis followed by implications and suggestions for future research.

\section{Theoretical development}

According to Smilor, et al. (1990), a university spin-off refers to a new venture founded by current students or faculty members of a university to develop and exploit their inventions based on an entrepreneurial process. University spin-offs are often conflated with other technology or research-based start-ups as they share common characteristics, and face similar difficulties in establishing market legitimacy and mobilizing their growth potential (Zahra, et al., 2007). However, university spin-offs significantly differ from other start-ups as they face two fundamental obstacles when they are initially launched (Vohora, et al., 2004; Wright, et al., 2006). First, university spin-offs originate from a non-commercial environment and academic entrepreneurs lack the necessary skills and resources that underpin the commercialisation process. Second, there is the opportunity for conflicting objectives as a result of the various stakeholders, the academic inventor, the university, the entrepreneurial team and equity investors that are often involved from an early stage of the spin-off process (Boardman and Ponomariov, 2009). As a consequence, the majority of spin-offs are unlikely to reach the growth phase (Vohora, et al., 2004) due to such 'liabilities of newness' (Stinchcombe, 1965) and this forces a university spin-off to rely on the reputation of the university or its technology transfer office to overcome these issues and provide market legitimacy (Pries and Guild, 2007). Some of the distinctive criteria that help distinguish university spin-offs from a broader category of technology start-ups include: the origin of the firm's core technology, the current or former affiliation of the founding member(s) with a particular parent organization, and the sources of funding used to start up the firm, all of which are in some form linked to a university. Furthermore, unlike other start-ups, the early-stage financial needs of USOs develop through three phases: seed capital is to support the research activities and develop the initial business concept, start-up finance is needed for early organizing efforts in business registration and early-growth finance is needed for the initial product development and market entry (Lindstrom and Olofsson, 2001; Shane, 2004; Vohora, et al., 2004; Lockett and Wright, 2005; Wright, et al., 2006). Rasmussen and Sørheim (2012) and Dimov and Murray (2008) found that the investors tend to abandon seed or early investments in favour of investing to a university spin-off in later or development stages.

\section{The nature of seed capital and unknowable risk}

Carpenter and Petersen (2002) indicated three reasons that affect the abilities of an academic entrepreneurial team to obtain early-stage investments. First, the low probability of financial success and the high failure rate of university spin-offs generate the uncertainty of investment returns discouraging the investment decisions of investors. Second, a university spin-off per se has a limited collateral value and a little salvage value in the event of failure. Third, information asymmetry exits regarding the worth of the spin-off with entrepreneurs in a position to decide what details about the potential business they will release to investors, limiting their ability to evaluate the proposition and increasing uncertainty (Certo, 2003). This asymmetric information can lead to the rejection of good investment 
opportunities or underinvestment (Myers and Majluf, 1984). Because the ultimate purpose is to maximize the benefit, investments are likely to be undertaken when financial providers can see the value of university spin-offs and mitigate the risks (Cumming and Johan, 2008).

However, in the earliest stages - seed capital - of university spin-offs, financial supporters face cases in which risks are unknowable: "They decide on investments in ideas for markets that often do not yet exist," and they were proposed new products and services without knowing whether those proposals will work (Huang and Pearce, 2015, p. 636). External investors make their decisions under unknowable risks with uncertain solutions rather than uncertainty (when risks are identified); it is equivalent to "chasing an invisible moving target" (Huang and Pearce, 2015, p. 636). In such cases, minimizing risks in each decision is not the most important goal, financial providers accept that they will lose most of their investments, but they seek for the promise of extraordinary success from “(relatively) small stakes at risk for each individual decision" (Huang and Pearce, 2015, p. 661).

Within the context of seed investments with unknowable risks, financial supporters will make their decisions based upon their intuitive judgments on extraordinary profitable investments (Huang and Pearce, 2015). These intuitive judgments base on the feeling of decision makers about whether entrepreneurial teams are trusted (Maxwell and Lévesque, 2014), are committed (Shane, 2004), and passionate (George, et al., 2008). Dane and Pratt (2007) believe that effectively charged judgments are the core of intuition and Wang and Saudino (2013) indicated that intuition has both affective and cognitive components embedding in a dynamic emotion-cognition interaction (Malatesta and Wilson, 1988). Huang and Pearce (2015, p. 660) then found that a process of seed investment decisions of external financial supporters is "truly emotion-cognition interactions".

Huang and Pearce (2015) have described the emotion-cognition interaction as an automatic yet sophisticated and complex domain-relevant process that involves formal analyses and intuitive judgments allows investors to make the most confident decisions. This process is based upon (1) business viability data that results from an investor's research on the business and financial plans of an entrepreneurial team, and (2) the team's perceptions referred to the signals of legitimacy derived from investor's personal 'observations' (Huang and Pearce, 2015). Investors are likely to feel confident to invest in proposals with a consistency between strong business viability data and positive perceptions of entrepreneurial teams, and conversely, investors tend to reject the projects with consistency between weak business viability data and negative perceptions of entrepreneurial teams (Huang and Pearce, 2015). In dissonance cases when business viability data is weak and the perceptions of entrepreneurial teams are positive, or vice versa, investors are likely to discount business viability data, prioritize their intuitions and rely heavily on their prior experience when making those unknowable types of decisions (Olson, et al., 2007; Huang and Pearce, 2015). Thus, it needs to discuss the role of emotion-cognition interaction in stimulating external financial supporters to clarify the contributions of social capital and entrepreneurial capabilities to the process that involves formal analyses and intuitive judgment.

\section{Entrepreneurial team's capabilities and emotion-cognition interaction}


The economic theory of entrepreneurship mostly emphasises the entrepreneurial function as the roles of a single person reflecting on his/her decision making, preferences, beliefs and actions (Harper, 2008). Although this research approach has long been appreciated, the notion that new ventures are more likely to be created by plural founders, is increasingly recognised (Gartner and Vesper, 1994). Recent research has indicated that entrepreneurial teams have become a more popular mode of a new business development (Lasch, et al., 2007) and the subject of assessments made by investors within early-stage financing processes (Hoenig and Henkel, 2015). This study thus focuses on investigating how potential investors measure and pick up information from the business and financial plans of academic entrepreneurial teams.

Within an emotion-cognition interaction, investors gather any numerically measurable information, such as potential market size, industrial growth and entrepreneurial background to assess the potential profitability of a project (Zacharakis and Meyer, 1998; Huang and Pearce, 2015). A business plan is the culmination of an arduous, creative and iterative process transforming a raw idea into an opportunity through presenting numerical information (Kirsch, et al., 2009), and commonly portrays an entrepreneurial team's motivation, goal orientation and perceived skills (Gruber, et al., 2008). Through such business plan, entrepreneurial teams can demonstrate their "entrepreneurial self-efficacy" (Chen, et al., 1998; Chen, et al., 2009; Kirsch, et al., 2009) by using their cognitive skills to gather, store, transform and interpret information and knowledge to determine appropriate actions (Baron, 2004). An entrepreneurial team with strong capabilities is likely to produce a high-quality business plan and propose feasible activities for a university spin-off process (Honig and Karlsson, 2004; Dencker, et al., 2009; Brinckmann, et al., 2010). In other words, an entrepreneurial team can use its capabilities to strengthen business viability data conveyed to potential investors, which eventually helps the team to win an approval from external financial supporters (Zacharakis and Meyer, 1998; Meseri and Maital, 2001; Huang and Pearce, 2015).

In dissonance cases, investors tend to downplay the roles of business viability data while prioritize the qualities of entrepreneurial teams who would execute the business plan, and could feel confident around their decisions (Huang and Pearce, 2015). An investment decision is likely to be made when investors prioritize positive assessments of the entrepreneurial teams over weak assessments of the business viability data (Huang and Pearce, 2015). However, investors are significantly less committed to projects in which they found strong assessments of business viability but negative assessments of the entrepreneurial teams (Huang and Pearce, 2015). Given the earliest stage of spinoffs seeking seed funding, conveying to investors the forms of business plans, entrepreneurial teams with highquality capabilities have ability to win positive impressions from investors and demonstrate the promisingly extraordinary profitability of their projects. For the purpose of this study, resource-based view (Barney, 1991) was employed to construct the capabilities of entrepreneurial teams consisting of entrepreneurial technology/know-how, organizational viability, entrepreneurial strategy, human capital and commercial resources. This study thus posits that (Figure 1):

H1: The capabilities of the university spin-off entrepreneurial teams will increase the likelihood of obtaining external seed capital. 


\section{Social networks and information for emotion-cognition interaction}

Huang and Pearce (2015) found that investors make their intuitive judgments strongly based upon the signals of legitimacy derived from the entrepreneurial team's credibility. These signals measured as the symbols of preparedness, commitment or trustworthy (Zott and Huy, 2007; Maxwell and Lévesque, 2014) are results from investor's communications with the teams or other parties to assess the personal characteristics of entrepreneurial teams (Huang and Pearce, 2015). According to Nofsinger and Wang (2011), entrepreneurial teams at early stages do not belong to professional networks in capital markets (e.g. networks for IPOs and SEOs pricing and distribution, co-underwrite offering networks, venture capitalist networks, etc.) and may thus rely on their social networks to communicate with investors.

Many scholars have proved that social networks provide a potential mechanism to exchange information between potential investors and entrepreneurial teams (Uzzi, 1996; Freiburg and Grichnik, 2012; Pinheiro, et al., 2015; Han and Heshmati, 2016). Relevant information about entrepreneurial teams can be conveyed by the knowledgeable parties or/and through screening activity which seeks for additional information from uninformed parties (Lee and Venkataraman, 2006; Carpentier, et al., 2010). Social networks convey to potential investors private information about the talents (Nofsinger and Wang, 2011), intentions, planned activities of entrepreneurial teams (Shane and Cable, 2002) and the value of spin-off projects (Granovetter, 2005), and leverage the trustworthy between entrepreneurial teams and financial providers (Kautonen, et al., 2010; Han and Heshmati, 2016). In addition, by associating with well-regarded individuals and organizations, entrepreneurial teams are able to increase their reputation determined by the information about past performance of the members of entrepreneurial teams (Podolny, 1994). The quality of social networks is a critical element providing important information about an entrepreneurial team which helps external financial supporters make their investment decisions based upon the emotion-cognition interactions. Investors may find positive perceptions of entrepreneurial teams through assessing this information because, as Newbert and Tornikoski (2013) believe, the academic members of entrepreneurial teams often have positive personal identity within their social networks. Investors who heavily rely on their experience and intuition are thus likely to be confident to make seed investment decisions. In another school of knowledge, other scholars believe that external investors are likely to be reluctant to invest in university spin-offs at early stages (Lockett and Wright, 2005; Clarysse, et al., 2007) due to academic entrepreneurial teams are often lacking of commercial capability and industrial links (Vanaelst, et al., 2006; Mosey and Wright, 2007; Bjornali and Gulbrandsen, 2010; Pinheiro, et al., 2015). However, academic entrepreneurial teams often possess strong technology capability (Ensley and Hmieleski, 2005) that determines the success of research and business concept developments, which are subject to seed capital. Thus, this study posits that the social networks of an entrepreneurial team may positively impact their financial acquisitions within the context of university spin-off's seed funding (Figure 1).

H2: The social networks of university spin-off entrepreneurial teams will contribute to obtaining external seed capital.

\section{Social networks and entrepreneurial team's capabilities}


It has been suggested that entrepreneurial teams need to exploit resources embedded within their networks to support the creation and growth of spin-offs (Shane, 2004; Vohora, et al., 2004; Walter, et al., 2006). However, academic founders originate from non-commercial environments and are constrained by relatively insular networks that provide limited access to individuals from industry integral to spin-off development (Mosey and Wright, 2007). Broadening the scope of networks is problematic as academic founders lack legitimacy with potential industry partners (Stinchcombe, 1965; Zahra, et al., 2007) and relationships created, under such conditions, are characterised by resource dependency and asymmetric power that limit a spin-off's ability to broker advantage. This is of concern as, where good industry links exist, a variety of resources (ideas, market information, problem solving, social support, and financial resources) are available (Shane and Cable, 2002; Hoang and Antoncic, 2003; Mosey and Wright, 2007) which increase an entrepreneurial team's ability to exploit new opportunities, enter new markets, or sell new products or services in existing markets (O'gorman, et al., 2008; Tolstoy and Agndal, 2010; Hayter, 2013). It is therefore important that entrepreneurial teams combine with technology transfer officers to take advantage of endowments available from the host university to strengthen capabilities, increase resources and broaden potential networks (Shane and Stuart, 2002; Clarysse, et al., 2007; Geuna and Muscio, 2009).

Resource types can be tangible or intangible in nature and include ideas, strategic advice (Yli-Renko, et al., 2001), access to financial providers (Rothschild and Darr, 2005; Kitagawa and Robertson, 2012), technology (Lockett and Wright, 2005), appropriate staff (Tolstoy and Agndal, 2010) and emotional support (Bruderl and Preisendorfer, 1998). In the case of USOs the social capital of a university can often confer security and scientific credibility that enables access to resource gatekeepers (Newbert and Tornikoski, 2013). Moreover where university incubators are employed, spin-offs will be able to take advantage of internal and external networks previously developed and fostered that can provide access to important information and resource (Kitagawa and Robertson, 2012). The value of networks to a spin-off depends upon the collective activities of the entrepreneurial team and university support mechanisms to identify, acquire and exploit appropriate networks (Chandler and Lyon, 2009). Entrepreneurial teams have the capacities to exploit the links with industrial sectors to support the development of commercial (Dubini and Aldrich, 1991), management and leadership expertise (Rothschild and Darr, 2005; Kitagawa and Robertson, 2012). The teams can also utilise co-operative links with university staff to access the latest knowledge and technology which reduces development costs (Markman, et al., 2005) in the creation of innovative products (Lockett and Wright, 2005). As these social networks develop, trust is enhanced between the entrepreneurial teams and their networks enabling them to bypass expensive search activity by utilising the network to reduce risk and limit the need for expensive due diligence when accessing key resources (Jones, et al., 1997). For the reasons identified, this paper proposes that the social networks of entrepreneurial teams, developed in conjunction with support from universities, can provide an important contribution to the resource and knowledge acquisitions of entrepreneurial teams (Fig. 1.).

H3: The capabilities of university spin-off entrepreneurial teams will be strengthened through its social networks. 


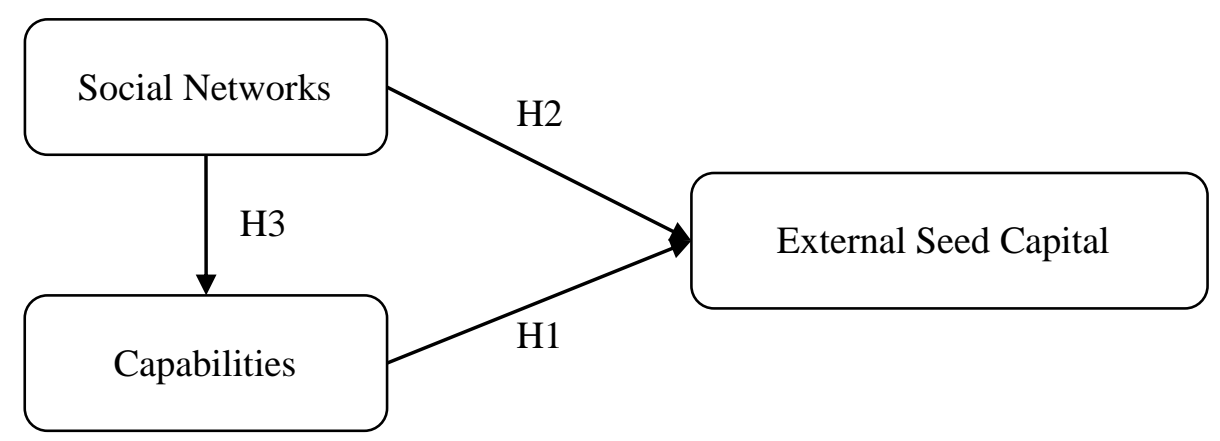

Fig. 1. Conceptual Model.

\section{Methodology}

\section{Sample}

This study draws the sample from 69 Spanish universities, each has an office for the transfer of research results (OTRI), located in 17 autonomous communities. OTRI's engage in a wide range of R\&D activities but only 35 are involved in the entrepreneurial processes of spin-offs. OTRIs are embedded in the sector and are the best source of fine-grained information about university spin-offs in Spain. It was through their offices that a dataset was developed of those spin-offs, created by teams, which included at least one academic member from a university. These criteria produced a dataset of 862 spin-offs that were subsequently surveyed using a web-based instrument in 2012; this survey resulted in 181 responses, 21 per cent of research population. All respondents were members of an entrepreneurial team and have a position on the executive board of the spin-off. The majority of spin-offs, 98 per cent, were created after 2003 inside a university incubator and come from a variety of sectors (see table 1).

Table 1. Descriptive Statistics

\begin{tabular}{crr}
\hline \multicolumn{1}{c}{ Variables } & $\mathrm{N}$ & $\%$ \\
\hline The status of respondents & & \\
$-\quad$ Academic founder & 181 & 100 \\
$-\quad$ Non-academic founder & 0 & 0 \\
Established location & 177 & 98 \\
$-\quad$ Inside University incubators & 4 & 2 \\
$-\quad$ Outside University incubators & 9 & \\
Spin-off's incorporation year & 29 & 16 \\
$-\quad 2011$ & 36 & 20 \\
$-\quad 2010$ & 24 & 13 \\
$-\quad 2009$ & 24 & 13 \\
$-\quad 2008$ & 25 & 14 \\
$-\quad 2007$ & 13 & 7 \\
$-\quad 2006$ & 9 & 5 \\
$-\quad 2005$ & 13 & 7 \\
$-\quad 2004$ & & \\
$-\quad$ In and before 2003 & & \\
Spin-off's industry &
\end{tabular}




\begin{tabular}{crr}
\hline - Information, computing and telecommunications & 61 & 33.8 \\
- Engineering and consultancy & 29 & 16.1 \\
- Medicine and health & 28 & 15.3 \\
- Agriculture and biotechnology & 27 & 15 \\
- Energy and environment & 16 & 8.9 \\
- Aeronautics and automotive & 8 & 4.3 \\
- Electronic & 6 & 3.3 \\
- Other industries & 6 & 3.3 \\
Regions in Spain & & \\
- Cataluña & 64 & 35.2 \\
- Andalucía & 39 & 21.6 \\
- País Vasco & 17 & 9.5 \\
- Valencia & 15 & 8.2 \\
- Madrid & 13 & 7.3 \\
- Castilla y León & 8 & 4.6 \\
- Asturias & 7 & 3.7 \\
- Other communities & 18 & 9.9 \\
Seed capital sources & & \\
- Internal capital & & \\
○ Personal savings, friends, or family & 94 & 52 \\
○ University grants & 30 & 16.6 \\
- External capital & & \\
$\quad$ Government grants & 68 & 37.6 \\
$\quad$ Banks & 25 & 13.8 \\
$\quad$ O Business angles & 16 & 8.8 \\
O Strategic partners & 13 & 7.2 \\
$\circ \quad$ Venture capitalists & 12 & 6.6 \\
\hline
\end{tabular}

\section{Construct measurements}

External seed capital. Binary variables were constructed to measure whether external financial resources, including government grants, banks, business angles, strategic partners and venture capitalists involve in providing seed capital for a university spin-off; one for at least one of external financial sources and zero for no external financial source. The entrepreneurial teams of these university spin-offs used seed capital funded by one or more sources: $52 \%$ from personal saving, friends, or family, $16.6 \%$ from university grants, $37.6 \%$ from government grants, $13.8 \%$ from banks, $8.8 \%$ from business angles, $7.2 \%$ from strategic partners, and $6.6 \%$ from venture capitalists.

Capabilities of entrepreneurial teams. Questions employ a seven-point Likert scale using constructs from existing entrepreneurship and management studies (Mcgrath, 1997; Antoncic and Hisrich, 2001; Lumpkin and Dess, 2001) to measure entrepreneurial technology, organizational viability, human capital, strategy and the commercial resource of entrepreneurial teams. In terms of entrepreneurial technology, respondents answered six questions about the ease of imitation, scope, continuity, and the market signals of their technology (Mcgrath, 1997). To measure the organizational viability, measurements were adapted from studies of Leonard-Barton (1992), Zahra (1993) and Antoncic and Hisrich (2001) to construct five questions that relate to internal communication mechanisms, formal control mechanisms and organizational support within entrepreneurial teams prior to incorporation. Human capital was subject to a four-item measurement tool, adopted from the studies of Alvarez and Busenitz (2001) and Mckelvie and Davidsson (2009), that evaluates the industrial, managerial knowledge, and work and entrepreneurial experience 
of the founders. The entrepreneurial strategy measurement employed questions that investigated levels of innovation, proactiveness, risk-taking, and competitive aggressiveness among the entrepreneurial team (Lumpkin and Dess, 2001). Finally, four questions based on the customer relationship, staff's technology training, and process design were used to measure the commercial resource available within entrepreneurial teams (Nadherny, 1998) (Appendix A).

Social networks. By adapting prior research, seven social network measurements employed seven-point Likert scales were constructed in the areas of centrality, ties, reputation, reciprocity, trust, information quality and diversity (Amit and Zott, 2001; Hoang and Antoncic, 2003). Centrality is based on the measurements of Rowley (1997) that evaluate the location of actors within information flows using four question about how directly respondents communicate with others within networks. The strength of an entrepreneurial-team's ties was measured by constructs that look at the willingness to engage in discussions with reference to social, political, and family matters (Parks and Floyd, 1996). By adapting the studies of Uzzi (1996) and Shane and Stuart (2002), a four-item measurement to evaluate the founder's reputation was constructed to obtain the views of other participants within networks. Reciprocity was measured by four questions that refer to the level of support received, accumulation of favours, and the fairness contained in the relationships among members (Miller and Kean, 1997). Furthermore, trust was measured by four questions which require respondents to self-report on how trustworthy they are perceived by other members within networks (Tsai and Ghoshal, 1998). To measure the quality of information within social networks five questions, developed by O'reilly Iii (1982), were employed which evaluate the accuracy, relevance, reliability, specificity, and timeliness of information. The availability of business relevant data was used to measure the diversity of information within networks; broken down into market data, product and process design data, marketing know-how, and packaging design or technology data (Gupta and Govindarajan, 2000) (Appendix A.

Control variables. The questionnaire requests each respondent to identify that they are a member of a spin-off entrepreneurial team and to confirm that at least one person from the entrepreneurial team was a student or worked at the university at the time the spin-off was established. To manipulate for the potential negative effect on abilities to obtain seed capital of a spin-off created outside a universities' incubator, this study will include a dummy variable coded one if spin-offs were created inside the parent incubators and zero otherwise. Moreover, this study identifies the age of a spin-off as a control variable that can influence seed investments of university spin-offs.

\section{Validity and reliability}

There is a potential error generated by the use of self-reporting from respondents especially as many of the measures are complex in nature and require post-hoc assessment. To reduce this common method bias, a series of proactive survey design has been undertaken (Spector, 2006): Previously validated measurements were employed, respondents were clearly confirmed that their answers are anonymous and not measured toward right or wrong, a pilot test on five spin-offs from the university of Granada was deployed to help fine tune the survey instrument. To test the impact of common method bias has on a research, Spector (2006) has suggested using the Harman's one-factor on 
all variables. The result from a Harman's one-factor test (33.79\%) suggests that the relationships between dependent and independent variables will not be caused by common method bias in this study.

To avoid measurement errors, the study conducted proper survey measures and used a construct validation test (the empirical indicators actually measure the construct) for validity (convergent and discriminant) and reliability by using confirmatory factor analysis (CFA). To assess convergent validity, the extent to which the indicators of measurement converge to a high proportion of variances in common, this study examines construct loadings and average variance extracted. The study constructs the exploratory factor analysis (EFA) of eleven factors: centrality, tie, reputation, reciprocity, trust, information quality, information diversity, entrepreneurial technology, organizational viability, human capital, strategy, and commercial resource. The results revealed that all standardized loadings estimates are higher than 0.5 (Appendix A). Moreover, all indexes of average variance extracted (AVE), the amount of construct variance relative to measurement error, are greater than 0.5 (Appendix B) suggesting adequate convergent validity.

Discriminant validity (i.e., unidimensionality) is to test whether a construct is truly distinct from other constructs. The results revealed that all AVE estimates are larger than the corresponding squared interconstruct correlation estimates (SIC) (Appendix B) inferring discriminant validity of the hypothesized structure is supported by our data.

This study computes the composite reliability, analogous to Cronbach's alpha, of all factors by the formula of Fornell and Larcker (1981). Most factors revealed sufficient composite reliabilities (above 0.70) except the reputation factor (0.644) (Appendix A). However, according to Hatcher (1994), the cut-off level of 0.6 is acceptable for a new conceptual variable. Moreover, construct reliabilities of all variables are greater than 0.7 (Appendix B), the measurements of this research, thus, are reliable.

\section{Results}

To test the research hypotheses, structural equation modelling (SEM) is used and three criteria suggested by extant literature (Bagozzi and Yi, 1988; Marsh, et al., 2004; Eddleston and Kellermanns, 2007; Lado, et al., 2008) are employed to address model fit. The normed $\chi^{2}$ (i.e., the ratio of $\chi^{2}$ to the degree of freedom) is required to be lower than 3; the root mean square error of approximation (RMSEA) is required to be lower than 0.06; and three indices comprising comparative fit index (CFI), incremental fit index (IFI) and the Tucker-Lewis index (TLI) all of which require a score greater than 0.9. Figure 2 shows that the structural model is a good fit $(\mathrm{CMIN} / \mathrm{DF}=1.312$, RMSEA $=0.042, \mathrm{CFI}=0.913, \mathrm{IFI}=0.915, \mathrm{TLI}=0.906)$ and appropriate to test the research hypotheses. The results (Fig. 2) indicate that the hypotheses 1 and 2 are not supported; the social networks and entrepreneurial capabilities of entrepreneurial teams have no impact on the possibility to obtain seed capital from external sources $(-0.057, \mathrm{p}=$ $0.546 ; 0.033, \mathrm{p}=0.746$ ). Whereas, social networks make a significantly positive influence on the entrepreneurial capabilities of an entrepreneurial team $(0.0305, p=0.012)$; it means that the hypothesis 3 is supported. In term of control variables, the results reveal that age has a significant positive $(0.278, p<0.001)$ influence upon the possibility of obtaining external seed capital of an entrepreneurial team. However, operating inside a university 
incubator does not help an entrepreneurial team to improve its possibility of obtaining external seed capital (-0.035, $\mathrm{p}=667)$.

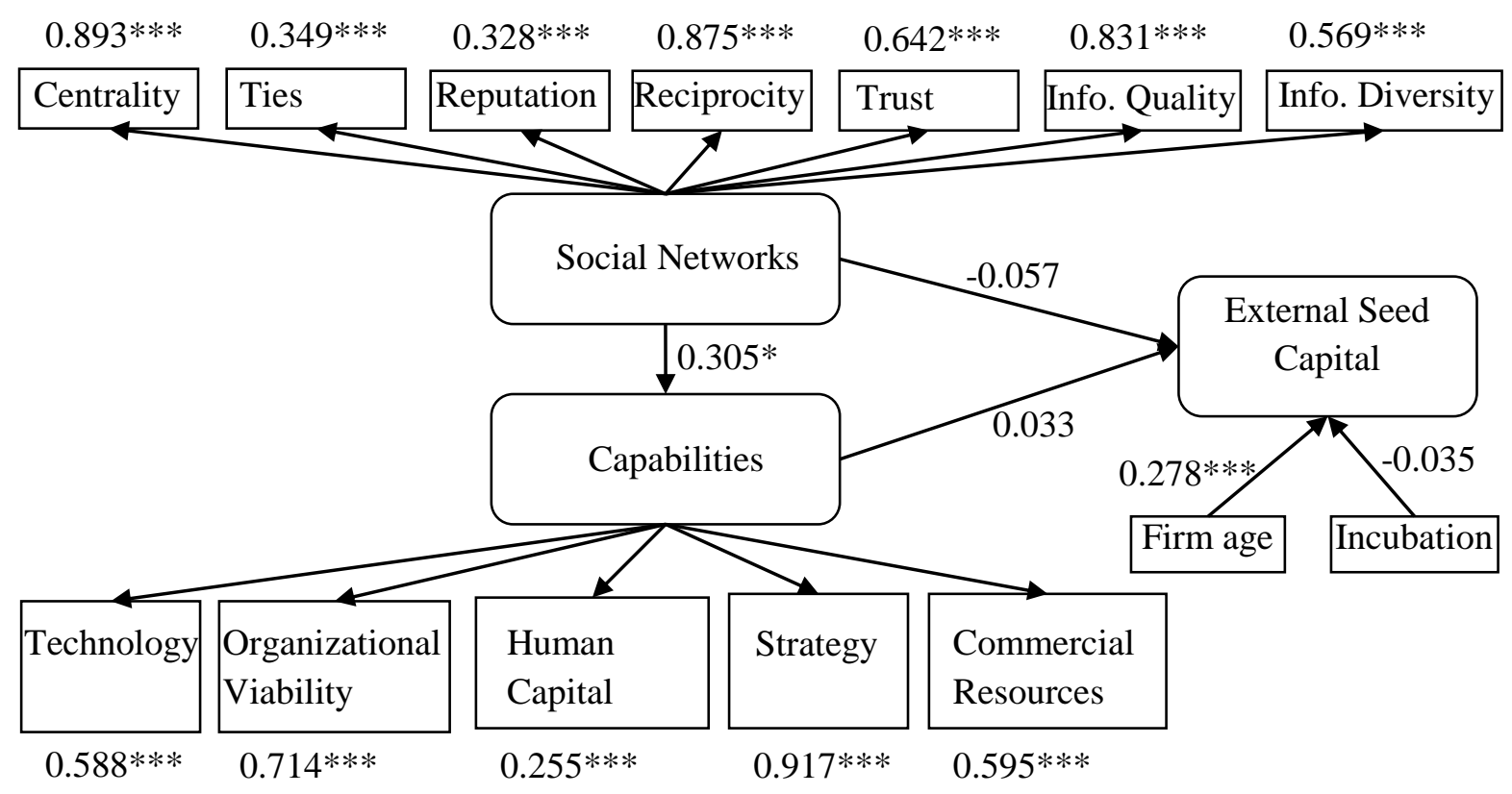

Model Fit: $C M I N / D F=1.312$, RMSEA $=0.042, C F I=0.913, I F I=0.915, T L I=0.906$;

$* p<0.05 ; * * p<0.01 ; * * * p<0.001 ;$ All error terms omitted for clarity.

Fig. 2. Structural Model.

\section{Fine-grained analysis}

The results from SEM were used to test research hypotheses, but how each type of external seed capital can be obtained is unclear. This study thus undertakes a fine-grained analysis to discover the nature of those influences. To construct the research indicators, exploratory factor analysis (EFA) was used. The results from the EFA of the network and capability measurements revealed that item loadings were mostly significant (over 0.5) (Appendix A). By using all items identified from the EFA, the average scores of all factors of social networks and capabilities of entrepreneurial teams were estimated before using logistic and linear regression models to test the research hypotheses.

The results from logistic regression analyses (Table 2) reveal that the entrepreneurial technology of an entrepreneurial team is likely to helpful in obtaining government grants for seed capital $(0.397, \mathrm{p}<0.05)$, whereas the team's commercial resources significantly positively influence the decisions of strategic partners $(0.330, \mathrm{p}<0.1)$ and commercial banks $(0.292, \mathrm{p}<0.05)$. The team's entrepreneurial strategy significantly positively influences the team's possibility of wining government grants $(0.336, \mathrm{p}<0.1)$ and receive seed investments from venture capitalists $(0.464$, $\mathrm{p}<0.1$ ). Meanwhile, the influences of the organizational viability of entrepreneurial teams on the likelihood of 
obtaining seed investments from business angels are significantly positive $(0.689, \mathrm{p}<0.001)$, but from strategic partners are significantly negative $(-0.375, \mathrm{p}<0.1)$.

Table 2 also shows that trust within social networks of an entrepreneurial team significantly positively influences the team's likelihood of obtaining seed investments from venture capitalists $(0.730, \mathrm{p}<0.05)$ and from commercial banks $(0.431, p<0.1)$. The central position of the team within it social networks has a positive influence on the decisions of strategic partners $(0.402, \mathrm{p}<0.1)$, but creates a negative impact on the likelihood to win government grants $(-0.358$, $\mathrm{p}<0.05)$. Other characteristics of social networks, such as reciprocity, reputation and information quality generate negative impacts on the possibility of obtaining seed investments from venture capitalists $(-0.396, p<0.1)$, business angels $(-0.617, \mathrm{p}<0.05)$ and commercial banks $(-0.404, \mathrm{p}<0.05)$ respectively. 
Table 2. Logistic regression models.

\begin{tabular}{|c|c|c|c|c|c|c|c|c|c|c|c|c|c|c|c|}
\hline \multirow[t]{2}{*}{ Variables } & \multicolumn{3}{|c|}{$\begin{array}{c}\text { Venture Capital } \\
\text { Model }\end{array}$} & \multicolumn{3}{|c|}{$\begin{array}{c}\text { Business Angel } \\
\text { Model }\end{array}$} & \multicolumn{3}{|c|}{$\begin{array}{l}\text { Strategic Partner } \\
\text { Model }\end{array}$} & \multicolumn{3}{|c|}{$\begin{array}{c}\text { Bank } \\
\text { Model }\end{array}$} & \multicolumn{3}{|c|}{$\begin{array}{c}\text { Government Grant } \\
\text { Model }\end{array}$} \\
\hline & $\mathrm{B}$ & S.E. & Wald & $\mathrm{B}$ & S.E. & Wald & $\mathrm{B}$ & S.E. & Wald & $\mathrm{B}$ & S.E. & Wald & $\mathrm{B}$ & S.E. & Wald \\
\hline Centrality & & & & & & & $0.402^{*}$ & 0.223 & 3.262 & & & & $-0.358 * *$ & 0.182 & 3.861 \\
\hline Trust & $0.730 * *$ & 0.348 & 4.392 & & & & & & & $0.431 *$ & 0.248 & 3.025 & & & \\
\hline Reciprocity & $-0.396^{*}$ & 0.239 & 2.753 & & & & & & & & & & & & \\
\hline Ties & & & & & & & & & & & & & & & \\
\hline Reputation & & & & $-0.617 * *$ & 0.307 & 4.054 & & & & & & & & & \\
\hline Information Quality & & & & & & & & & & $-0.404 * *$ & 0.160 & 6.361 & & & \\
\hline Information Diversity & & & & & & & & & & & & & & & \\
\hline Entrepreneurial Technology & & & & -0.188 & 0.178 & 1.119 & & & & & & & $0.397^{* *}$ & 0.159 & 6.207 \\
\hline Organizational Viability & -0.461 & 0.288 & 2.566 & $0.689^{* * * *}$ & 0.258 & 7.122 & $-0.375^{*}$ & 0.222 & 2.849 & & & & & & \\
\hline Entrepreneurial Strategy & $0.464^{*}$ & 0.264 & 3.085 & & & & & & & & & & $0.336^{*}$ & 0.184 & 3.317 \\
\hline Human Capital & 0.118 & 0.140 & 0.706 & & & & & & & & & & & & \\
\hline Commercial Resources & & & & & & & $0.330^{* *}$ & 0.160 & 4.258 & $0.292 * *$ & 0.130 & 5.060 & -0.130 & 0.140 & 0.864 \\
\hline University Incubator & -0.433 & 1.226 & 0.125 & 19.79 & 1696 & 0 & 19.66 & 1738 & 0 & 0.059 & 1.029 & 0.003 & -1.331 & 0.071 & 2.016 \\
\hline University Spin-off's Age & $0.140^{*}$ & 0.076 & 3.403 & 0.053 & 0.073 & 0.513 & -0.053 & 0.081 & 0.431 & $0.29 * * * *$ & 0.073 & 15.886 & 0.101 & 1.731 & 0.093 \\
\hline Chi-square & & $6.921 * *$ & & & $295 * * *$ & & & $1.214 *$ & & & $.023 * *$ & & & $.786 * * *$ & \\
\hline Cox \& Snell R Square & & 0.089 & & & 0.071 & & & 0.060 & & & 0.167 & & & 0.099 & \\
\hline
\end{tabular}

$* * * * p<0.001 ; * * * p<0.01 ; * * p<0.05 ; * p<0.1$ 


\section{Discussions}

This paper investigates the impact on the seed capital of university spin-offs as a consequence of the capabilities and social networks exhibited by entrepreneurial teams associated with their creation prior to incorporation. The results from our models suggest that, in general, the social networks and entrepreneurial capabilities of an entrepreneurial team make no significant contributions to help the team in obtaining seed capital from external sources. It has been noticed that seed investment decisions were made based upon intuitive judgments on extraordinary profitability resulted from the emotion-cognition interactions of investors (Huang and Pearce, 2015). This judgment process is based on the business viability data and perceptions of entrepreneurial teams obtained by investors through researching business and financial plans, communications and personal observations. This study complements to the emotion-cognition interaction framework Huang and Pearce (2015) which focuses on the supply side (investors) by shedding light on the demand perspective. The results indicate that, through social networks, negative perceptions of entrepreneurial teams and weak business viability data will be conveyed to external investors, which eventually decrease the likelihood of obtaining external seed capital. This study indicates that the social networks of entrepreneurial teams have more negative impacts than positive influences on the likelihood of obtaining external seed capital. Among social network characteristics, trust has a positive influence on obtaining seed capital from venture capitalists and banks, and the centrality, helping to convey positive personal information, intentions, planned activities and credibility of entrepreneurial teams, increases possibility of obtaining seed funding from strategic partners. However, in obtaining seed capital from government, network centrality shows negative impact, and the influences of reciprocity on venture capital, reputation on business angel, and information quality on banks are also negative. This finding helps to introduce a new school of knowledge that, depending on the sources of external capital, the social networks of entrepreneurial teams may have positive or negative influences.

In regard to each type of capital sources, entrepreneurial strategy and technology, organizational viability and commercial resources are key capabilities of entrepreneurial teams needed to access external seed capital from government, banks, strategic partners, business angles and venture capital. This finding is supported by evidence from the study of Rea (1989) which indicated that the success of a seed capital negotiation is associated with the market opportunities, business plan and completeness of entrepreneurial teams. The results contribute to our theoretical knowledge of university seed funding, especially why a small amount of academic entrepreneurial teams has been successful in obtaining external seed investments while the majority of the USOs have failed or never consider to seek for external seed capital.

It has been suggested that early stage firm founders are often reluctant to admit the need to expand their capabilities but are uncertain about how best to acquire such capabilities (Baker and Nelson, 2005); this often leads to entrepreneurial capacity being constrained (Hughes, et al., 2007). This research suggests that the entrepreneurial teams of university spin-offs have limited capabilities and networks that can be supplemented by university support. The role of networks in enhancing an entrepreneurial team's capabilities has been well documented in the literature relating to new ventures. However, this study identifies a need to pay more attention to the entrepreneurial team and the process by which they build some aspects of capabilities and network characteristics prior to incorporation. This 
paper argues that it is in the interest of those involved in university spin-offs to enhance the capabilities and of the entrepreneurial team prior to incorporation and that this should be a clear purpose of a university technology transfer office or incubation facility. The model, which was developed to predict the success of pitch for seed capital of university spin-offs before significant capital has been expended, substantially benefits the members of an entrepreneurial team, supporters, resource suppliers, researchers, and public and university policy. While a great deal of work in this area is already undertaken it is important for such agencies to facilitate an understanding of, and improvement in, entrepreneurial technology, organizational viability, entrepreneurial strategy and commercial skill sets through greater interaction with business through joint continuing professional development programmes, internships and secondments.

\section{Conclusions}

The research is distinctive in its focus upon university spin-offs by embedding resource-based view and social network theory into university entrepreneurship studies; this paper broadens the contexts in which this relevant theory can be applied. This paper explores academic entrepreneurial teams to enrich our knowledge of the impact of capabilities and social networks of entrepreneurial teams have on the engagement of external supporters in seed investments. Resource-based view was employed to evaluate the capabilities of entrepreneurial teams and the conceptual model of Hoang and Antoncic (2003) to scrutinize the characteristics of social networks. The results from an examination of the sample of 181 Spanish university spin-offs demonstrate that social networks can help an entrepreneurial team to shape its capabilities, which improve its possibility of obtaining various types of external seed capital, but social networks are also convey information that negatively impacts the team's likelihood of obtaining such funding.

The results from this empirical study suggest that in obtaining seed capital from various external financial sources academic entrepreneurial teams should build some characteristics of social networks and develop some specific capabilities. Government grants, the most common seed capital for university spin-offs, could be accessed easier if entrepreneurial teams possess good technologies, entrepreneurial strategies, commercial resources, and advanced ties and trust within social networks. Building the trustworthiness within social networks and commercial skills, as well as technology, strategy, human capital, organizational viability, network reputation and reciprocity may help entrepreneurial teams to pitch for financial support from banks. Commercial skills, technology, strategy, human capital, and centrality, reputation and reciprocity within social networks will help entrepreneurial teams to improve the probability to engage strategic partners and obtain more seed capital from those partnerships. The entrepreneurial strategy, ties, centrality and information quality within social networks of entrepreneurial teams are likely to be crucial criterion that influence the possibility of obtaining seed capital from business angels. Finally, venture capital, as the less common seed capital source for university spin-offs, is likely to be easier to access if entrepreneurial teams obtain trust from their social networks and have strong entrepreneurial strategies, technology, organizational viability, commercial resources. Overall, entrepreneurial strategy and trust within social networks are likely to be the most important determinants that influence the likelihood of obtaining external seed capital. 
While the findings from the study are robust, it is acknowledged that there are areas within the research process that could impinge upon the validity and reliability of the work. This study's sample size was restricted because of the limitation on the number of spin-offs from Spanish universities; nevertheless, this sample reflects $21 \%$ of all spinoffs in Spain between 2003 and 2010. The survey is also based upon a non-random sample as respondents were selected on the basis of their potential to provide the level of detail which could enhance our understanding of the phenomena based upon the judgement of OTRI officers in Spain. In addition, the data was collected using an internet survey which has the potential to be misinterpreted but these issues were carefully explored during the pilot phase of the empirical work. It is also possible that respondents to the survey may exhibit a certain cognitive bias based on post-hoc rationalisation. To mitigate this common bias, a series of proactive survey designs has been adapted, but an experimental approach is suggested to eliminate this common method bias from future similar studies. Another limitation of this study is that it measures the capabilities and social networks of a team, but the information on which the findings are based is derived from one member of that team; this process could generate a bias in which the evaluations of an individual might not fully reflect the nature of the whole team. To mitigate those limitations, future studies associated with seed capital are thus suggested to undertake longitudinal surveys on external investors or on all members of academic entrepreneurial teams. The results from this study have been validated within the context of Spanish university spin-offs, to generate more reliable results and refinements in entrepreneurship studies, future studies on seed capital can extend their focuses to other European university spinoffs and other types of new ventures.

\section{References}

Alvarez, S.A. and L.W. Busenitz, 2001, The entrepreneurship of resource-based theory, Journal of Management 27(6), 755-775.

Amit, R. and C. Zott, 2001, Value creation in e-business, Strategic Management Journal 22(6-7), 493520.

Antoncic, B. and R.D. Hisrich, 2001, Intrapreneurship: Construct refinement and cross-cultural validation, Journal of Business Venturing 16(5), 495-527.

Bagozzi, R.P. and Y. Yi, 1988, On the evaluation of structural equation models, Journal of the Academy of Marketing Science 16(1), 74-94.

Barney, J., 1991, Firm resources and sustained competitive advantage, Journal of Management 17(1), 99120.

Baron, R.A., 2004, The cognitive perspective: A valuable tool for answering entrepreneurship's basic "why" questions, Journal of Business Venturing 19(2), 221-239.

Bjornali, E.S. and M. Gulbrandsen, 2010, Exploring board formation and evolution of board composition in academic spin-offs, Journal of Technology Transfer 35(1), 92-112.

Bjørnåli, E.S., R. Sørheim and T. Erikson, 2010, 'Design characteristics associated with venture capital acquisitions in academic spin-offs,' in C.G. Brush, R. Sørheim, L.Ø. Widding and L. Kolvereid (eds.), From The life cycle of new ventures: A cross national investigation, Williston, VT: Edward Elgar Pub.

Boardman, P.C. and B.L. Ponomariov, 2009, University researchers working with private companies, Technovation 29(2), 142-153.

Brinckmann, J., D. Grichnik and D. Kapsa, 2010, Should entrepreneurs plan or just storm the castle? A meta-analysis on contextual factors impacting the business planning-performance relationship in small firms, Journal of Business Venturing 25(1), 24-40. 
Bruderl, J. and P. Preisendorfer, 1998, Network support and the success of newly founded businesses, Small Business Economics 10(3), 213-227.

Carpenter, R.E. and B.C. Petersen, 2002, Capital market imperfections, high-tech investment, and new equity financing, The Economic Journal 112(477), F54-F72.

Carpentier, C., J.-F. L'Her and J.-M. Suret, 2010, Stock exchange markets for new ventures, Journal of Business Venturing 25(4), 403-422.

Certo, S.T., 2003, Influencing initial public offering investors with prestige: Signaling with board structures, Academy of Management Review 28(3), 432-446.

Chandler, G.N. and D.W. Lyon, 2009, Involvement in knowledge-acquisition activities by venture team members and venture performance, Entrepreneurship: Theory \& Practice 33(3), 571-592.

Chen, C.C., P.G. Greene and A. Crick, 1998, Does entrepreneurial self-efficacy distinguish entrepreneurs from managers?, Journal of Business Venturing 13(4), 295-316.

Chen, X.P., X. Yao and S. Kotha, 2009, Entrepreneur passion and preparedness in business plan presentations: A persuasion analysis of venture capitalists' funding decisions, Academy of Management Journal 52(1), 199-214.

Clark, C., 2008, The impact of entrepreneurs' oral 'pitch' presentation skills on business angels' initial screening investment decisions, Venture Capital 10(3), 257-279.

Clarysse, B., M. Wright, A. Lockett, P. Mustar and M. Knockaert, 2007, Academic spin-offs, formal technology transfer and capital raising, Industrial and Corporate Change 16(4), 609-640.

Cumming, D. and S. Johan, 2008, Information asymmetries, agency costs and venture capital exit outcomes, Venture Capital 10(3), 197-231.

Dane, E. and M.G. Pratt, 2007, Exploring intuition and its role in managerial decision making, Academy of Management Review 32(1), 33-54.

Dencker, J.C., M. Gruber and S.K. Shah, 2009, Pre-entry knowledge, learning, and the survival of new firms, Organization Science 20(3), 516-537.

Dimov, D. and G. Murray, 2008, Determinants of the incidence and scale of seed capital investments by venture capital firms, Small Business Economics 30(2), 127-152.

Douglas, E.J. and D. Shepherd, 2002, Exploring investor readiness: Assessments by entrepreneurs and investors in australia, Venture Capital 4(3), 219-236.

Dubini, P. and H. Aldrich, 1991, Personal and extended networks are central to the entrepreneurial process, Journal of Business Venturing 6(5), 305-313.

Eddleston, K.A. and F.W. Kellermanns, 2007, Destructive and productive family relationships: A stewardship theory perspective, Journal of Business Venturing 22(4), 545-565.

Ensley, M.D. and K.A. Hmieleski, 2005, A comparative study of new venture top management team composition, dynamics and performance between university-based and independent start-ups, Research Policy 34(7), 1091-1105.

Fornell, C. and D.F. Larcker, 1981, Evaluating structural equation models with unobservable variables and measurement error, Journal of Marketing Research 18(1), 39-50.

Franke, N., M. Gruber, D. Harhoff and J. Henkel, 2008, Venture capitalists' evaluations of start-up teams: Trade-offs, knock-out criteria, and the impact of vc experience, Entrepreneurship: Theory \& Practice 32(3), 459-483.

Freiburg, M. and D. Grichnik, 2012, Institutional investments in private equity funds: Social ties and the reduction of information asymmetry, Venture Capital 14(1), 1-26.

Gartner, W.B. and K.H. Vesper, 1994, Experiments in entrepreneurship education: Successes and failures, Journal of Business Venturing 9(3), 179-187.

George, G., R. Kotha and Y.F. Zheng, 2008, Entry into insular domains: A longitudinal study of knowledge structuration and innovation in biotechnology firms, Journal of Management Studies 45(8), 1448-1474.

Geuna, A. and A. Muscio, 2009, The governance of university knowledge transfer: A critical review of the literature, Minerva 47(1), 93-114. 
Granovetter, M., 2005, The impact of social structure on economic outcomes, Journal of Economic Perspectives 19(1), 33-50.

Gruber, M., I.C. MacMillan and J.D. Thompson, 2008, Look before you leap: Market opportunity identification in emerging technology firms, Management Science 54(9), 1652-1665.

Gupta, A.K. and V. Govindarajan, 2000, Knowledge flows within multinational corporations, Strategic Management Journal 21(4), 473.

Han, J. and A. Heshmati, 2016, Determinants of financial rewards from industry-university collaboration in south korea, International Journal of Innovation Management 20(07), 1650075.

Harper, D.A., 2008, Towards a theory of entrepreneurial teams, Journal of Business Venturing 23(6), 613-626.

Hatcher, L., 1994, A step by step approach to using the sas system for factor analysis and stuctural equation modeling Cary, NC: SAS Institute Inc.

Hayter, C.S., 2013, Harnessing university entrepreneurship for economic growth: Factors of success among university spin-offs, Economic Development Quarterly 27(1), 18-28.

Hoang, H. and B. Antoncic, 2003, Network-based research in entrepreneurship - a critical review, Journal of Business Venturing 18(2), 165-187.

Hoenig, D. and J. Henkel, 2015, Quality signals? The role of patents, alliances, and team experience in venture capital financing, Research Policy 44(5), 1049-1064.

Honig, B. and T. Karlsson, 2004, Institutional forces and the written business plan, Journal of Management 30(1), 29-48.

Huang, L. and J.L. Pearce, 2015, Managing the unknowable: The effectiveness of early-stage investor gut feel in entrepreneurial investment decisions, Administrative Science Quarterly 60(4), 634-670.

Hughes, M., P. Hughes and R.E. Morgan, 2007, Exploitative learning and entrepreneurial orientation alignment in emerging young firms: Implications for market and response performance, British Journal of Management 18(4), 359-375.

Huynh, T., 2016, Early-stage fundraising of university spin-offs: A study through demand-site perspectives, Venture Capital 18(4), 345-367.

Huynh, T., D. Patton, D. Arias-Aranda and L.M. Molina-Fernández, 2017, University spin-off's performance: Capabilities and networks of founding teams at creation phase, Journal of Business Research 78, 10-22.

Jones, C., W.S. Hesterly and S.P. Borgatti, 1997, A general theory of network governance: Exchange conditions and social mechanisms, Academy of Management Review 22(4), 911-945.

Kamm, J.B., J.C. Shuman, J.A. Seeger and A.J. Nurick, 1990, Entrepreneurial teams in new venture creation: A research agenda, Entrepreneurship: Theory \& Practice 14(4), 7-17.

Kautonen, T., R. Zolin, A. Kuckertz and A. Viljamaa, 2010, Ties that blind? How strong ties affect small business owner-managers' perceived trustworthiness of their advisors, Entrepreneurship \& Regional Development 22(2), 189-209.

Kirsch, D., B. Goldfarb and A. Gera, 2009, Form or substance: The role of business plans in venture capital decision making, Strategic Management Journal 30(5), 487-515.

Kitagawa, F. and S. Robertson, 2012, High-tech entrepreneurial firms in a university-based business incubator. Spaces of knowledge, resource heterogeneity and capital formation, The International Journal of Entrepreneurship and Innovation 13(4), 249-259.

Lado, A.A., R.R. Dant and A.G. Tekleab, 2008, Trust-opportunism paradox, relationalism, and performance in interfirm relationships: Evidence from the retail industry, Strategic Management Journal 29(4), 401-423.

Lasch, F., F. Le Roy and S. Yami, 2007, Critical growth factors of ict start-ups, Management Decision 45(1), 62-75.

Lee, J.H. and S. Venkataraman, 2006, Aspirations, market offerings, and the pursuit of entrepreneurial opportunities, Journal of Business Venturing 21(1), 107-123.

Leonard-Barton, D., 1992, Core capabilities and core rigidities: A paradox in managing new product development, Strategic Management Journal 13, 111-125. 
Lindstrom, G. and C. Olofsson, 2001, Early stage financing of ntbfs: An analysis of contributions from support actors, Venture Capital 3(2), 151-168.

Lockett, A. and M. Wright, 2005, Resources, capabilities, risk capital and the creation of university spinout companies, Research Policy 34(7), 1043-1057.

Lumpkin, G.T. and G.G. Dess, 2001, Linking two dimensions of entrepreneurial orientation to firm performance: The moderating role of environment and industry life cycle, Journal of Business Venturing 16(5), 429-452.

Malatesta, C.Z. and A. Wilson, 1988, Emotion cognition interaction in personality-development - a discrete emotions, functionalist analysis, British Journal of Social Psychology 27, 91-112.

Markman, G.D., P.H. Phan, D.B. Balkin and P.T. Gianiodis, 2005, Entrepreneurship and university-based technology transfer, Journal of Business Venturing 20(2), 241-263.

Marsh, H.W., K.-T. Hau and Z. Wen, 2004, In search of golden rules: Comment on hypothesis-testing approaches to setting cutoff values for fit indexes and dangers in overgeneralizing hu and bentler's (1999) findings, Structural Equation Modeling: A Multidisciplinary Journal 11(3), 320 341.

Mason, C.M. and R.T. Harrison, 2004, Does investing in technology-based firms involve higher risk? An exploratory study of the performance of technology and non-technology investments by business angels, Venture Capital 6(4), 313-332.

Maxwell, A.L. and M. Lévesque, 2014, Trustworthiness: A critical ingredient for entrepreneurs seeking investors, Entrepreneurship: Theory \& Practice 38(5), 1057-1080.

McGrath, R.G., 1997, A real options logic for initiating technology positioning investments, Academy of Management Review 22(4), 974-996.

McKelvie, A. and P. Davidsson, 2009, From resource base to dynamic capabilities: An investigation of new firms, British Journal of Management 20, S63-S80.

Meseri, O. and S. Maital, 2001, A survey analysis of university-technology transfer in israel: Evaluation of projects and determinants of success, The Journal of Technology Transfer 26(1-2), 115-125.

Miller, N.J. and R.C. Kean, 1997, Reciprocal exchange in rural communities: Consumers' inducements to inshop, Psychology \& Marketing 14(7), 637-661.

Mosey, S. and M. Wright, 2007, From human capital to social capital: A longitudinal study of technology-based academic entrepreneurs, Entrepreneurship Theory and Practice 31(6), 909935.

Muzyka, D., S. Birley and B. Leleux, 1996, Trade-offs in the investment decisions of european venture capitalists, Journal of Business Venturing 11(4), 273-287.

Myers, S.C. and N.S. Majluf, 1984, Corporate financing and investment decisions when firms have information that investors do not have, Journal of Financial Economics 13(2), 187-221.

Nadherny, C.C., 1998, Technology and direct marketing leadership, Direct Marketing 61(7), 42.

Newbert, S.L. and E.T. Tornikoski, 2013, Resource acquisition in the emergence phase: Considering the effects of embeddedness and resource dependence, Entrepreneurship Theory and Practice 37(2), 249-280.

Nofsinger, J.R. and W. Wang, 2011, Determinants of start-up firm external financing worldwide, Journal of Banking \& Finance 35(9), 2282-2294.

O'Gorman, C., O. Byrne and D. Pandya, 2008, How scientists commercialise new knowledge via entrepreneurship, Journal of Technology Transfer 33(1), 23-43.

O'Reilly III, C.A., 1982, Variations in decision makers' use of information sources: The impact of quality and accessibility of information, Academy of Management Journal 25(4), 756-771.

Olson, M.A., R.H. Fazio and A.D. Hermann, 2007, Reporting tendencies underlie discrepancies between implicit and explicit measures of self-esteem, Psychological Science 18(4), 287-291.

Ortín-Ángel, P. and F. Vendrell-Herrero, 2010, Why do university spin-offs attract more venture capitalists?, Venture Capital 12(4), 285-306.

Parks, M.R. and K. Floyd, 1996, Meanings for closeness and intimacy in friendship, Journal of Social and Personal Relationships 13(1), 85-107. 
PINHEIRO, M.L., C. LUCAS and J.C. PINHO, 2015, Social network analysis as a new methodological tool to understand university-industry cooperation, International Journal of Innovation Management 19(01), 1550013.

Podolny, J.M., 1994, Market uncertainty and the social character of economic exchange, Administrative Science Quarterly 39(3), 458-483.

Powers, J.B. and P.P. McDougall, 2005, University start-up formation and technology licensing with firms that go public: A resource-based view of academic entrepreneurship, Journal of Business Venturing 20(3), 291-311.

Pries, F. and P. Guild, 2007, Commercial exploitation of new technologies arising from university research: Start-ups and markets for technology, $R \&$ D Management 37(4), 319-328.

Rasmussen, E. and R. Sørheim, 2012, How governments seek to bridge the financing gap for university spin-offs: Proof-of-concept, pre-seed, and seed funding, Technology Analysis \& Strategic Management 24(7), 663-678.

Rasmussen, E. and R. Sørheim, 2012, Obtaining early-stage financing for technology entrepreneurship: Reassessing the demand-side perspective, Venture Capital 14(2/3), 77-89.

Rea, R.H., 1989, Factors affecting success and failure of seed capital/start-up negotiations, Journal of Business Venturing 4(2), 149-158.

Riding, A., B. Orser and T. Chamberlin, 2012, Investing in r\&d: Small- and medium-sized enterprise financing preferences, Venture Capital 14(2/3), 199-214.

Rosman, A.J. and H.M. O'Neill, 1993, Comparing the information acquisition strategies of venture capital and commercial lenders: A computer-based experiment, Journal of Business Venturing 8(5), 443 460.

Rothschild, L. and A. Darr, 2005, Technological incubators and the social construction of innovation networks: An israeli case study, Technovation 25(1), 59-67.

Rowley, T.J., 1997, Moving beyond dyadic ties: A network theory of stakeholder influences, Academy of Management Review 22(4), 887-910.

Shane, S., 2004, Academic entrepreneurship: University spin-offs and wealth creation Cheltenham, UK: Edward Elgar.

Shane, S. and D. Cable, 2002, Network ties, reputation, and the financing of new ventures, Management Science 48(3), 364-381.

Shane, S. and T. Stuart, 2002, Organizational endowments and the performance of university start-ups, Management Science 48(1), 154-170.

Shepherd, D.A. and A. Zacharakis, 1999, Conjoint analysis: A new methodological approach for researching the decision policies of venture capitalists, Venture Capital 1(3), 197-217.

Silva, J., 2004, Venture capitalists' decision-making in small equity markets: A case study using participant observation, Venture Capital 6(2-3), 125-145.

Smilor, R.W., D.V. Gibson and G.B. Dietrich, 1990, University spin-out companies - technology start-ups from university-of-texas-at-austin, Journal of Business Venturing 5(1), 63-76.

Soetanto, D. and M. van Geenhuizen, 2015, Getting the right balance: University networks' influence on spin-offs' attraction of funding for innovation, Technovation 36-37(0), 26-38.

Spector, P.E., 2006, Method variance in organizational research - truth or urban legend?, Organizational Research Methods 9(2), 221-232.

Stinchcombe, A.L., 1965, 'Social structure and organizations,' in J. March (ed.), From Handbook of organizations, Chicago, IL: Rand McNally, pp. 142-193.

Tolstoy, D. and H. Agndal, 2010, Network resource combinations in the international venturing of small biotech firms, Technovation 30(1), 24-36.

Tsai, W.P. and S. Ghoshal, 1998, Social capital and value creation: The role of intrafirm networks, Academy of Management Journal 41(4), 464-476.

Tsukagoshi, M., 2008, The expected roles of business angels in seed/early stage university spin-offs in japan: Can business angels act as saviours?, Asia Pacific Business Review 14(3), 425-442. 
Uzzi, B., 1996, The sources and consequences of embeddedness for the economic performance of organizations: The network effect, American Sociological Review 61(4), 674-698.

Vanaelst, I., B. Clarysse, M. Wright, A. Lockett, N. Moray and R. S'Jegers, 2006, Entrepreneurial team development in academic spinouts: An examination of team heterogeneity, Entrepreneurship Theory and Practice 30(2), 249-271.

Vohora, A., M. Wright and A. Lockett, 2004, Critical junctures in the development of university hightech spinout companies, Research Policy 33(1), 147-175.

Walter, A., M. Auer and T. Ritter, 2006, The impact of network capabilities and entrepreneurial orientation on university spin-off performance, Journal of Business Venturing 21(4), 541-567.

Wang, M.J. and K.J. Saudino, 2013, Cognition \& emotion: Reviews of current research and theories, American Journal of Psychology 126(1), 128-132.

Wiltbank, R., S. Read, N. Dew and S.D. Sarasvathy, 2009, Prediction and control under uncertainty: Outcomes in angel investing, Journal of Business Venturing 24(2), 116-133.

Wright, M., A. Lockett, B. Clarysse and M. Binks, 2006, University spin-out companies and venture capital, Research Policy 35(4), 481-501.

Yli-Renko, H., E. Autio and H.J. Sapienza, 2001, Social capital, knowledge acquisition, and knowledge exploitation in young technology-based firms, Strategic Management Journal 22(6-7), 587-613.

Zacharakis, A.L. and G.D. Meyer, 1998, A lack of insight: Do venture capitalists really understand their own decision process?, Journal of Business Venturing 13(1), 57-76.

Zahra, S.A., 1993, Environment, corporate entrepreneurship, and financial performance - a taxonomic approach, Journal of Business Venturing 8(4), 319-340.

Zahra, S.A., E. Van de Velde and B. Larrañeta, 2007, Knowledge conversion capability and the performance of corporate and university spin-offs, Industrial \& Corporate Change 16(4), 569608.

Zott, C. and Q.N. Huy, 2007, How entrepreneurs use symbolic management to acquire resources, Administrative Science Quarterly 52(1), 70-105. 


\section{Appendix A: Descriptions of variables, Cronbach's alphas and factor loadings}

Reliving this spin-off's creation phase, evaluating these statements about relationships between your team and individuals, who you received advice or information related to process of your firm's incorporation, and among them, and evaluating these statements about what the entrepreneurial team possessed (1: Not true...7: Very true).

\begin{tabular}{|c|c|c|c|}
\hline & Measures & Loadings & $\begin{array}{l}\text { Cronbach's } \\
\text { Alpha }\end{array}$ \\
\hline \multirow[t]{5}{*}{ Centrality } & & & 0.736 \\
\hline & We talked directly about business issues & 0.781 & \\
\hline & We received directly helpful business information & 0.697 & \\
\hline & We could call for advice about running our business & 0.712 & \\
\hline & We were the first to receive new things in the group & 0.670 & \\
\hline \multirow[t]{4}{*}{ Ties } & & & 0.840 \\
\hline & We would share personal matters with them & 0.804 & \\
\hline & We might discuss family matters with them & 0.918 & \\
\hline & We might ask them for advice about private matter & 0.885 & \\
\hline \multirow[t]{4}{*}{ Reputation } & & & 0.644 \\
\hline & We generated a lot of enthusiasm & 0.787 & \\
\hline & We persevered until the task is finished & 0.750 & \\
\hline & We liked to play with ideas & 0.766 & \\
\hline \multirow[t]{5}{*}{ Reciprocity } & & & 0.805 \\
\hline & People were generally pair in dealings with us & 0.776 & \\
\hline & People were willing to do us a favour if asked & 0.733 & \\
\hline & We did favours for each other from time to time & 0.817 & \\
\hline & People patronized my business & 0.900 & \\
\hline \multirow{5}{*}{ Trust } & & & 0.879 \\
\hline & We were dependable by these people & 0.863 & \\
\hline & People would say that we are sincere & 0.888 & \\
\hline & They would trust us with personal information about themselves & 0.822 & \\
\hline & They would say that we are trustworthy & 0.894 & \\
\hline Information & & & 0.926 \\
\hline Quality & Their information was usually accurate & 0.895 & \\
\hline (information used & Their information was relevant & 0.909 & \\
\hline \multirow[t]{3}{*}{ to be exchanged) } & Their information was specific & 0.887 & \\
\hline & Information from them was often & 0.846 & \\
\hline & I quickly received their information & 0.852 & \\
\hline Information & & & 0.922 \\
\hline Diversity & Market data & 0.812 & \\
\hline (information used & Product design & 0.874 & \\
\hline \multirow[t]{4}{*}{ to be exchanged) } & Process design & 0.863 & \\
\hline & Marketing know-how & 0.853 & \\
\hline & Packaging design/technology & 0.848 & \\
\hline & Management system and practices & 0.838 & \\
\hline Entrepreneurial & & & 0.847 \\
\hline \multirow[t]{5}{*}{ Technology } & Our products might replace numerous existing one & 0.843 & \\
\hline & Might replace other technologies in the industry & 0.784 & \\
\hline & Potential to generate large economic returns & 0.821 & \\
\hline & A platform for variety of commercial applications & 0.706 & \\
\hline & Developed products with considerable demand in market & 0.808 & \\
\hline Organizational & & & 0.794 \\
\hline Viability & Team's members were encouraged to improve working method & 0.793 & \\
\hline
\end{tabular}




\begin{tabular}{|c|c|c|c|}
\hline & Team's members had power to make decisions & 0.740 & \\
\hline & Rewards and reinforcement were used & 0.824 & \\
\hline & Individuals had time to incubate innovative ideas & 0.674 & \\
\hline & Training in working techniques and attitudes was major emphasis & 0.668 & \multirow{5}{*}{0.829} \\
\hline \multirow{4}{*}{ Human Capital } & & & \\
\hline & Good business management knowledge & 0.737 & \\
\hline & Good industrial experience & 0.710 & \\
\hline & Good entrepreneurial experience & 0.792 & \\
\hline Entrepreneurial & & & \multirow[t]{5}{*}{0.758} \\
\hline \multirow[t]{4}{*}{ Strategy } & $\begin{array}{l}\text { Strong emphasis on } \mathrm{R} \& \mathrm{D} \text {, technological leadership, and } \\
\text { innovation }\end{array}$ & 0.746 & \\
\hline & $\begin{array}{l}\text { The first to introduce new products and services, administrative } \\
\text { technologies, etc... }\end{array}$ & 0.708 & \\
\hline & $\begin{array}{l}\text { Strong tendency to be ahead of other competitors in introducing } \\
\text { novel ideals and products }\end{array}$ & 0.803 & \\
\hline & The team was very aggressive and intensely competitive & 0.653 & \\
\hline Commercial & Good plan to redesign management process & 0.823 & \\
\hline \multirow{2}{*}{ Resource } & Good plan to redesign marketing and sales process & 0.860 & \\
\hline & Improving company processes as a key of our business plan & 0.747 & \\
\hline
\end{tabular}

Appendix B: Reliability and validity tests

\begin{tabular}{|c|c|c|c|}
\hline & $\begin{array}{l}\text { Construct } \\
\text { Reliability } \\
\text { (CR) }\end{array}$ & $\begin{array}{c}\text { Average } \\
\text { Variance } \\
\text { Extracted } \\
\text { (AVE) }\end{array}$ & $\begin{array}{l}\text { Squared Interconstruct Correlation } \\
\text { (SIC) }\end{array}$ \\
\hline \multicolumn{4}{|l|}{ Social Network } \\
\hline Centrality & 0.8076 & 0.5129 & \\
\hline Ties & 0.9033 & 0.7575 & $0.01 ; 0.15 ; 0.09$ \\
\hline Reputation & 0.8116 & 0.5895 & $0.18 ; 0.28 ; 0.06$ \\
\hline Reciprocity & 0.8827 & 0.6542 & $0.06 ; 0.03 ; 0.001$ \\
\hline Trust & 0.9238 & 0.7521 & $0.32 ; 0.53 ; 0.19$ \\
\hline Information Quality & 0.9439 & 0.7711 & $0.13 ; 0.10 ; 0.25$ \\
\hline Information Diversity & 0.9390 & 0.7195 & \\
\hline \multicolumn{4}{|l|}{ Capabilities } \\
\hline Entrepreneurial Technology & 0.8946 & 0.6301 & $0.085 ; 0.03$ \\
\hline Organizational Viability & 0.8591 & 0.5512 & $0.21 ; 0.14$ \\
\hline Human Capital & 0.7909 & 0.5582 & $0.04 ; 0.24$ \\
\hline Entrepreneurial Strategy & 0.8190 & 0.5322 & $0.06 ; 0.08$ \\
\hline Commercial Resource & 0.9364 & 0.6583 & $0.05 ; 0.22$ \\
\hline
\end{tabular}

